\title{
Teachers as Moral Compasses: Exploring Critical Literacy through Digital Social Justice Book Talks
}

\author{
JANETTE M. HUGHES \\ University of Ontario Institute of Technology \\ LORAYNE ROBERTSON \\ University of Ontario Institute of Technology
}

\begin{abstract}
A classroom-based study aimed to scaffold pre-service teachers' critical literacy through an exploration of trade picture books. The paper discusses pre-service teachers' shifting views of critical literacy and the place of critical literacy in the language arts classroom. It also assesses the usefulness of digital book talks for engaging pre-service teachers with social justice issues. The book talks provided novice teachers with opportunities to question and challenge assumptions, evaluate their own actions and attitudes toward accepted moral standards, and to engage in positive social action. The pre-service teachers' responses to the assignment suggest a number of ways in which teachers can effectively use new media to explore social justice and equity issues with young students.
\end{abstract}

\section{Introduction}

In this initial teacher education classroom-based research, we scaffolded critical literacy skills by exploring trade picture books through a social justice lens. The purpose of the study was threefold. We examined (1) pre-service teachers' shifting views of critical literacy and its place in the language arts classroom: (2) digital book talks as a way of engaging pre-service teachers with social justice issues in active ways, and (3) pre-service teachers' views about social justice and their role as a "moral compass" during classroom discussions about social justice. We wanted students to understand that the classroom is not a neutral space. Like it or not, teachers are responsible for assisting their students' in making complex ethical decisions and choices based on beliefs and values. In this paper we examine what happened when pre-service teachers were asked to engage with picture books through an analysis and critique of the power relationships among texts, language, social groups and social practices. Each pre-service teacher was asked to select a picture book that contained a social justice message, present the book using a critical literacy lens, and relate the student activities and unpacking of the books to one or more of the assigned readings. These readings covered topics such as: privilege (McIntosh, 2008); social justice (Moller, 2002); critical literacy (Leland, Harste \& Smith, 2005); and diverse family structures (Gilmore \& Bell, 2006)

The pre-service teachers were assigned the task of designing a lesson using a critical literacy lens and asking such questions as: What voices are heard and what voices are missing? How is the reader positioned in the text? How would this story be different if it was told from the perspective of a different character? We asked them to examine and challenge the attitudes, values and beliefs that lie beneath the surface of the text and to consider ways that this kind of critique might empower teachers and students to participate in a democratic society and move literacy beyond text to social action. Following this analysis, 
the pre-service teachers created digital book talks that drew attention to a specific social justice issue.

Every student in our Initial Teacher Education program has a laptop with hardware and software that can be used for educational purposes, as well as access to the Internet. Our language and literacy program begins by plunging students headfirst into the rich depths of multiple literacies: including multimodal literacies, critical media literacy, critical literacy, and digital literacies - depths we maintain throughout the course. Our course goals include developing in our students the capacity to look beyond the literal meaning of text and media and embrace their complexities. We wanted our students to observe what was present and what was missing and to focus on issues of fairness, equity, and social justice. We also hoped to encourage our pre-service teachers to be proficient users of technology, but more importantly, questioners and producers of technology (Selber, 2004). The first three assignments in the course aimed to encourage and facilitate these goals. Their first assignment - a personal digital literacy story - was complex in its media but also in its duality; it positioned them as producers as well as consumers of media. We encouraged them to find meaning in their own literacy experiences and to reflect and seek deeper meaning from both the production and the viewing of each others' stories, considering how literacies develop within a global context of education and society's constructed realities of advantage and difference (Hughes \& Robertson, 2010; Robertson \& Hughes, 2010). The second assignment required the pre-service teachers to create a digital book talk - a brief overview or introduction to a book designed to generate student interest. A companion article (Robertson \& Hughes, this issue) reflects on the third assignment, a critical media literacy lesson. Although our analysis of the book talks suggests that pre-service teachers are capable of and even adept at creating media texts, we suggest in the companion article that they are sometimes challenged by the complex demands embedded in critical media literacy explorations.

In this article, we focus on the digital book talks created by four of our pre-service teachers. (These are linked so that they can be viewed by readers). We analyze the effectiveness of each of the book talks based on a variety of criteria, including its potential to motivate students to read the book, its success as a multimodal text that might engage students, and the quality of the questions related to the social justice topic raised.

\section{Why Booktalks?}

The booktalk assignment has two components: (1) the digital book talk itself, and (2) a written rationale for selecting the book, which includes a discussion of how the book might be used with students. The two components link theory to practice. Book talks are a powerful tool for students of all ages because of their potential to place books into the hands of students who might not choose to read them (Fischbaugh, 2004). They have been used primarily to motivate children to read, and we know that motivation plays an important role in learning and has a great effect on the amount and scope of students' reading. But we contend that book talks go beyond just motivating students to read; they offer students a greater understanding of the wide range of books available to them and of important issues. They can inspire students to take action. For this reason, we require that the pre-service teachers select a book that has a clear social justice issue and ask them to consider how they would use this book in their classroom to encourage their students to take action.

\section{Why Social Justice Booktalks?}

Various approaches to teaching for social justice have been suggested, particularly over the past decade, including but not limited to critical multicultural and anti-bias education 
(Derman-Sparks \& Ramsey, 2006; Schniedewind \& Davidson, 2006; Sleeter, 2005), antiracist teaching (Berlak \& Moyenda, 2001), and anti-oppressive teacher education (Kumashiro, 2004). Our orientation focuses on critical, social justice teacher education (Bigelow, Harvey, Karp \& Miller, 2001; Christensen, 2001, 2009; Cochran-Smith, 2004; Agarwal et al, 2010; Sleeter, 2005; Soohoo, 2006; Wade, 2007) and teaching for social change (Darling-Hammond, French, \& Garcia-Lopez, 2002; Oakes \& Lipton, 2007). More specifically, we designed our program to challenge pre-service teachers to question dominant narratives, to create and enact learning opportunities that are inclusive and to integrate multiple perspectives, to facilitate the development of a social consciousness in themselves and their own students, and to create spaces and opportunities for students to discuss issues of injustice, and to take action as engaged citizens. Some discussion takes place within the context of the first assignment - presenting their own personal digital narratives and realizing that they, themselves and their peer pre-service teachers have been both privileged and oppressed in diverse and multiple ways. Further classroom discussion on privilege and injustice is prompted through the deliberate selection of the early course readings where we ask the pre-service teachers to examine challenging topics such as heteronormativity (Gilmore \& Bell, 2006) and other positions that privilege or disadvantage others (e.g., eurocentrism).

We acknowledge that there are different perspectives which classroom teachers can elect to undertake with respect to social justice issues: (1) to respect traditional authority without questioning its underlying assumptions; (2) to encourage a pluralist view where the teacher remains neutral; or (3) to encourage a more active questioning of social inequality (Kelly \& Brandes, 2001). In this assignment, in a deliberate way, we were encouraging the pre-service teachers to move away from a neutral position. Although it is not uncommon to examine social injustices, like gender and class inequities in a pre-service language arts course, there still exists some reluctance or even resistance on the part of beginning teachers to the idea of raising sensitive issues with young students. Year after year, some of them tell us that young children should not be exposed to books that explore sensitive issues such as sexuality, racism, mental illness or abuse. They argue that the "world is hard enough. Why not protect them from such things until they are older?" "There are plenty of books that depict positive, happy situations. Why not focus our attention on those?" Others argue that they "personally agree" that power differentials begin even before our children step onto the school playground and that there is a place for picture books that explore sensitive issues in the curriculum; however, they report being "uncomfortable" as beginning teachers introducing these books to their future students for fear of reprisals from parents or the administration. It is because of such views that we decided to require our pre-service teachers to create a social justice book talk for young students. Pre-service teachers view a variety of exemplary digital book talks and, drawing on critical literacy texts and a wide variety of picture books, they construct their own social justice digital book talk.

As Wolk and Labbo (2004) point out, the number of picture books for English speaking children that deal with social justice issues has been steadily on the rise: "There are picture books that explore cultural appreciation and peace, empathy and compassion, social responsibility and activism, community and the common good - all vital qualities to a democratic society" (p. 27) and these books can help all of us "shape our political, cultural, and moral identities" (p. 27). Our findings certainly indicate that creating book talks that focus on social justice issues can generate awareness of the issues themselves, and also of the pedagogical and moral challenges implicit in using such books with young students. As O'Neil (2010) points out, the books are important for children's development. She argues that teachers use social justice picture books to "prompt debate and discussion about issues 
that touch the lives of their students" and that "immersion in literature that generates critical analysis of the status quo can open students to new perspectives, prepare students for current and coming challenges to traditional ways of being, and perhaps even stimulate them to launch their own challenges to the old order" (p. 41). In some cases, the creation of the social justice book talks led to the pre-service teachers taking action against bullying, poverty or discrimination in their local communities. Because the book talks are posted online, the preservice teachers have access to a bank of book talks to use with their students and they can use their digital book talk as a sample for their students, particularly with junior/intermediate students, who might create their own book talks. Further, this project goes beyond the typical examination of social injustice in picture books because it requires that pre-service teachers apply a critical literacy lens to construct a digital book talk of their own for the primary grades, which moves them beyond talking and reading about social/political issues, to deconstructing the text messages and taking action.

\section{Why Digital Book Talks?}

Using new media in the construction/representation of social justice book talks offers benefits to both pre-service teachers and their students. The creation of the book talk offers pre-service teachers an opportunity to practice an important instructional skill and enables them to practice expressing their ideas in multiple modes. One of our primary aims is to prepare our pre-service teachers to teach in a digital age, to become familiar with the out-ofschool literacy practices of their students, and to consider how they might use these media for educational purposes in their own classrooms. Reading or writing a digital text entails new forms of semiotic processing of the combinations of the visual, audio, textual, gestural, spatial and linguistic (New London Group, 1996). Creating a digital book talk requires the pre-service teachers to consider elements of design (New London Group, 2000) as they choose the most appropriate features for effectively communicating their message to an audience. As the New London Group point out, multimodal design "represents the patterns of interconnection among the other modes" (p. 25) and they identify different elements that constitute each mode of meaning. For example, visual design could include such elements as colour, perspective, foregrounding, backgrounding and the like. Design choice and multimodal understanding of the communicative ability of how modes work in concert to communicate meaning requires producers to be critical readers in making choices (Bearne, 2003; Jewitt, 2008; Mayer, 2008) and it creates an awareness of the challenges involved for the pre-service teachers who will be asking their students to participate in similar activities. In particular, the use of digital storytelling software encourages students to create personal voice in their writing and to use their own voices in the book talk through voice-over narration. Digital book talks also combine image, sound (through soundtrack and voice-over) and text to reflect a multimodal, media-literacy approach to creating these teaching resources. New media technology facilitates the convergence of multiple modes in one medium, which fosters the strengths of diverse learners. (Short, Kauffman \& Kahn, 2000; Wilhelm, 1995). Because the book talks are digital, they can be shared with a wider audience. In fact, one of these book talks now resides on the publisher's website (http://secondstorypress.ca/books/137-lily-and-the-paper-man ). In this article, we share four examples that show how pre-service teachers use digital media to create their book talks and to illuminate ways that they draw upon and extend their own experiences with both the issues and the technology. To view the digital book talks, go to Hughes' e-book at http://faculty.uoit.ca/hughes/Reading/QualityLiterature.html. 


\section{Homelessness, Holocaust and Heroics: Four Case Studies}

We use a case study method, which is suitable for collecting in-depth stories of teaching and learning. The case study method is also appropriate for studying a 'bounded system', that is, the thoughts and actions of participating students or the learning/community connection of a particular education setting, so as to understand it as it functions under natural conditions (Stake, 2000). The analysis is qualitative in keeping with the established practice of in-depth studies of classroom-based learning and case studies in general (Stake, 2000). Case study data consists of (a) initial surveys about pre-service teachers' understanding of critical literacy; (b) their written reflections; (c) the digital book talks created by pre-service teachers; and (d) open-ended interviews with selected pre-service teachers, some of whom had opportunities to use the book talks with their students on field placement. Approximately ninety book talks were analyzed for this research, and were rated based on the following criteria:

- potential to motivate students to read the book;

- success as a multimodal text that might engage students;

- quality of the questions related to the social justice topic raised.

Based on their digital and textual artistry and effectiveness, we considered other questions such as, "Overall, is the book talk artistically appealing and narrated with inflection and enthusiasm? Does the book talk move beyond the basic criteria, such as mentioning the book's title, author and illustrator and giving enough information or context about the story without giving too much away? Do the images, sound (narration and musical soundtrack), text on screen, special effects, and transitions complement the book talk or are they fragmented or superfluous? Does the book talk present a unified social justice message? Are students prompted to engage with the book through critical questions or a call to imagination?" For the purposes of this article, we have chosen to examine in detail four of the most successful book talks in close detail. These book talks are based on Lily and the Paper Man by Rebecca Upjohn (2007), December by Eve Bunting (1997); The Harmonica by Tony Johnston (2003), and The Librarian of Basra by Jeannette Winter (2005), Together, they address the social justice issues of homelessness; the holocaust; and heroism as civil disobedience.

\section{Motivating Students to Read (aka. "the sales pitch")}

The first category of analysis was a consideration of how well the book talk would motivate students to read the book. The digital book talks utilized several methods to encourage students to read. One method was presenting an explicit literary sales pitch, such as "You'll have to read the rest of the book to find out..." Sometimes this sales pitch is worked into the text in a relatively fluid way. Other times the sales pitch is inserted rather awkwardly, such as in the December book talk:

You will have to read the story to find out what Simon decided to do. But that night, after they went to sleep, something happened. Read the story of December to find out what happens to Simon and his mother on that magical Christmas Eve when miracles are known to occur.

Here the vague statement "something happened" is sandwiched between two sentences repeating the same sales pitch, "read the story..." Either way, such sales pitches seem to be a distraction from the social justice issues: a clear, unified message is not presented (is the talk 
about reading, or about a social justice issue?) and the artistic world of the book talk is interrupted to a greater or lesser degree.

In general, the book talks tended to withhold the climax or conclusion of the books to pique students' curiosity and prompt them to read the book. The four book talks referred to in this article, while not revealing "everything that happened," still provided an adequate context in which students could engage the social justice issues with which they were presented. In contrast, some of the less successful book talks failed to provide enough information for a fully satisfying discussion on the social justice issue. For example, some begin with an assumption such as "it's okay to be different" or "prejudice is bad," but an adequate discussion or explanation of the assumptions is not provided, nor is a rich context for engagement. This impedes fruitful discussion on the social justice issues being raised. In presenting the literary sales pitch and in limiting the amount of the book presented, the book talks often gave literacy skills and strategies precedence over social justice issues. Students' difficulties in this regard illuminate the complexity of the task: to encourage students to read while providing them with an opportunity to think critically about a social justice issue and consider how the multimodal affordances of new media might support those goals.

Some key features set the more successful book talks apart from the others. For example, three out of four of the best book talks only utilize illustrations from the book. Perhaps this strategy helped to build the atmosphere and recreate the world of the book. In comparison, all of the less successful book talks utilize images, primarily from the internet, in addition to the book's illustrations. Also, none of the four best book talks provided additional information about the book and author over and above the title and the names of the author and illustrator. Perhaps such information distracts from the focus of the book talk and/or interrupts the artistic feel. Placement of the book's details also seems to be important. Three of the four best book talks provided information about the book at the end of the book talk. By contrast, most of the least successful book talks placed such information at the beginning. This suggests that generally, beginning the book talk with information about the book detracts from the artistic or textual value of the book. On the one hand, this might seem counterintuitive. Wouldn't it be better to present the information about the book first and then move on to create a mood and world uninterrupted? Those book talks that introduce the book information at the beginning create a classroom sense, suggesting "time to read," instead of "time to imagine". The book talks that created mood and an artistic world from the start were most effective. Movie trailers certainly seem to work this way, launching us into the action of the film and then providing the details (release date, stars and director, etc.) at the end. The need to minimize these kinds of distractions arises to a large degree from the need to create and maintain a mood and artistic world that will capture students' interests, provide a context within which to engage with social justice questions, and motivate them to action.

\section{Looking at the "Big Picture": Using Digital Media to Engage Students.}

We know that new media capture interest and engage viewers, so the book talk authors' effective use of digital media was the second criterion for analysis. The special benefit of digital book talks stems from their ability to spark students' interest in social justice questions and to provide an engaging context in which students can grapple with these questions in multimodal ways. Interest is sparked through the skilful usage of digital media, probably more so than through even a good reading of a passage from the book. An engaging context is built through creating a world that students can enter and in which they can interact. Such a world is created through the development of mood (using music, voice tone, etc.) and through introducing the book's setting, characters, and plot in sufficient detail. By 
creating a world inhabited by characters, students are no longer simply addressing (for example) the problem of 'homelessness' but are meeting specific homeless people - like Simon in December or the paper man in Lily and the Paper Man - and students are encouraged to wrestle with those problems alongside the characters in the story.

Book talks can set up the themes to be developed in the story, through a juxtaposition of text and images, without revealing too much of the plot. The book talk based on The Harmonica is a good example of this. Through pictures and text, this book talk communicates elements of the story, such as the main character's loss of his parents and the misery of the concentration camp, but the summary remains relatively vague: What happened to the boy's parents? What are the details of life in the concentration camp? The book talk succeeds in building a dramatic and entrancing world without giving away the story. This would be harder (although not impossible) to do in class, where pictures, music, and voice cannot be combined so freely.

Further, digital media allow the world of the book to be brought closer to home. In the December book talk, for example, the book's illustrations are supplemented by a picture of a Christmas tree with gifts underneath, a sight with which many students are probably familiar. Juxtaposing this familiar image with the scanty Christmas tree belonging to the book's homeless characters enriches students' learning experience and helps them to comprehend the story and issue. Book talks go beyond the limitations of the printed text.

There are other ways in which digital book talks can go beyond the text, allowing for an engaging and enriched learning experience. Although music is a key element in helping to create a specific mood for a book talk, music can also serve to elaborate the themes or social issues in the book. For example, one pre-service teacher based her book talk on Vaunda Micheaux Nelson's (2003) book, Almost to Freedom, about a young girl and her mother who escape from slavery, she used the background music of Follow the Drinking Gourd, an American folksong, whose lyrics are associated with the Underground Railroad.

\section{Asking Critical Questions and Challenging Assumptions}

Part of the success of the book talks must be attributed to interspersing questions that keep students engaged. The book talks raise four main categories of questions: imaginative/predictive questions, self-evaluative questions, problem-solving questions and textual analysis questions. The imaginative/predictive questions encourage students to engage imaginatively and thoughtfully with the text and with their world - making connections, forming predictions, seeking to understand motives and mindsets (e.g. "What do you think will happen?" "What do you think this book is about?" "Why might X have acted this way?") Self-evaluative questions encourage students to examine their own beliefs, motives, attitudes, and actions. (e.g. "How would you feel in this situation?" "Would you have had the courage to do X?") These questions can prompt students to examine the issues from personal and multiple perspectives. Problem solving questions encourage students to consider practical solutions to the social justice question(s) posed by the book talk. (e.g. "How could this be changed?" "What can we do to prevent X?") These questions promote students to consider ways of taking action to address social injustices. A fourth category of questioning, related to textual analysis, appears only rarely. These questions encourage students to critically examine the text and author, including any explicit and/or hidden perspectives, motives and/or messages: "How else could this text be interpreted?" "How would another person tell this story?" "What is the genre of this text?" In the section that follows, we examine how the pre-service teachers have asked such questions for each of the four selected book talks. 
The Librarian of Basra.

Jeanette Winter recounts the "true story" of Alia Muhammad Baker, librarian of Basra, who together with her friends, saved the vast majority of the library's books before it was destroyed during the American invasion of Iraq in 2003. The narrative and illustrations put a human face on the impact of war, particularly on its civilians, and emphasizes that the love of books and knowledge is an important value that brings people of all cultures together. Winter hopes the book will encourage children to "take with them the belief that one person can truly make a difference. And that they would remember the bravery of one woman protecting what was important to her, especially when they feel powerless, as we all do sometimes" (Harcourt website).

In summarizing the story in the book talk based on this picture book, the narrator asks the question, "Does she listen to the government's orders...or does she listen to her heart and protect the [books]...?" Later, she makes this question personal: "Would you defy the government and risk your life to save thousands of books? These are provocative questions as they deal with the issue of civil disobedience. Should the students assume they ought to disobey the government any time something that is precious to them is at stake? The presentation of the main character as a heroine is fruitful ground for critical investigation and challenging questions. The narrator approaches the issues in the story by asking her students to imagine "that this foreign place is actually your hometown, and it only seems like you're stranded, because there are suddenly people there you don't recognize, and your life is being threatened." This sentence invites students into a world of differing interests, power struggles, and moral choices. Critical questions such as "What kinds of social realities does the text portray?" are not so much asked as experienced.

\section{Lily and the Paper Man.}

Rebecca Upjohn skilfully addresses the issue of homelessness through the eyes of her young protagonist, Lily, who encounters a man who looks "different" selling papers near her home. Lily avoids her usual route home in an effort to steer clear of the Paper Man; however, when the weather turns cold and winter sets in, Lily worries about how he will stay warm with the holes in his shoes and with no hat, scarf or mittens. Upjohn's story was inspired by her own son's reaction to seeing a homeless man in downtown Toronto and she "began to think about what a young child could do to help someone on the street" (Upjohn's website: http://www.rebeccaupjohn.com/serve.pl?page=Books.LilyAndThePaperMan).

The author of the book talk based on Lily and the Paper Man recognizes that we may hold preconceived notions that can and perhaps should be examined: "What's our immediate reaction to those people who aren't as fortunate as us - to a homeless person?" "What is it that scares us sometimes about homeless people?" These questions invite us to consider our own feelings without immediately forcing a conclusion on us (i.e. a "be nice to a homeless person" message). Such questions come close to interrogating the text, inviting us to challenge it with our own reactions. The further question "Do you think one dollar would really make a difference in someone else's life?" also challenges the text in an attempt to help students see the significance of one small gift. The book talk does not indicate whether one course of action or one sort of attitude is right or wrong. It allows students, like the main character, to develop feelings and attitudes regarding the paper man and to struggle with the question of how they might or ought to act if they were in the same situation.

\section{The Harmonica.}

Tony Johnston tells the gripping story of a young Polish boy, separated from his parents during World War II and sent to a concentration camp where he is ordered by a Nazi 
guard to play his harmonica for the guard's entertainment. The harmonica, a gift from his father, helps the boy and his fellow captives remain hopeful in the face of the horrors of the camp. Readers cannot help but be engrossed in this unusual picture book, which offers a short historical snapshot exposing the ugliness of racism and the power of hope. Johnston, who based his story on the experience of Henryk Rosmaryn, a survivor of the Dyhrenfurth concentration camp, notes that it is a story of "the power of music and the strength of the human heart" (author's note).

The creators of the book talk based on The Harmonica raised questions that that do not have easy answers and, therefore, could be investigated in more detail. For example, what is the correct answer to the following question: "Would you bring attention to yourself if it meant helping others?" Presumably students are to give the answer "yes." Like many of the book talks, then, this book talk assumes a number of basic principles. For example, the book talk seems to suggest that courage, unselfishness, and optimism are good, while hatred, cruelty, cowardice, and defeatism are bad. Yet these principles are not necessarily shared by everyone - as the original text of the story shows. Students are not asked to question the perspective that supports these principles. Instead, working from these principles, they are encouraged to evaluate themselves.

\section{December.}

As is the case with many of her books, author Eve Bunting deftly explores an important and sensitive social issue - homelessness. This time, in contrast to Lily in Lily and the Paper Man, the story is told from the perspective of a Simon, a homeless boy who lives in a cardboard box with his mother. On Christmas Eve, an elderly woman seeks shelter with them in the box and Simon shares one of his two cookies that he is saving for a Christmas Day treat with her. The next day, the old woman has disappeared but Simon sees their Christmas calendar angel outside, with her wings fanned out. The following Christmas Eve, after Simon and their mother find themselves in better circumstances - living in an apartment of their own and his mother employed - Simon wonders if the old woman was a real angel after all.

The book talk asks questions that pique the imagination but does not focus on issues of social justice, nor does it question the text itself. It encourages agreement with the text when asking, "Simon is scared. Wouldn't you be?" More critical questions might be, for example, "How often do we see poverty talked about in books? How often do we think about /talk about poverty and homelessness? Why is this topic comfortable or not comfortable for us?"

\section{Seeking the Critical Literacy Questions}

The majority of questions posed by the creators of the book talks were either related to making predictions or responding personally to the text. Questions such as "What do you think this book will be about?" or "What would you do if you were X?" were typical, but these sorts of questions simply require students to form predictions about the text as opposed to analyzing or critiquing it. Fewer questions were posed that deal with practical activism or problem-solving. They refrained from asking challenging questions that deconstruct the text, such as, "Why is the text this way?" or "Should the text be this way?"- questions which deal critically with the hidden aspects of the text. Such questions are almost completely absent from the book talks. This is significant because the majority of the sample critical literacy questions we provided to the pre-service teachers as model questions focus on deconstruction of the text. It is possible that the book talk format is not conducive to asking these kinds of questions, perhaps because only small portions of the actual text are being shared with the 
students. The competing demands of the assignment, to persuade the reader to read the text and deconstruct some of the issues embedded in the text, are perhaps not wholly reconcilable. Although there are exceptions, most of the book talks seem to take for granted the social justice message they present. Students are invited to form predictions, explain how they would feel in certain situations, and/or brainstorm for practical solutions, but they are not encouraged to grapple with the central issue itself. Students are expected to come to the text with certain basic moral beliefs or values already firmly in place. A good illustration of this is provided by the book talk based on the book The Harmonica. This book talk concludes with the following series of questions for the reader to consider or perhaps even to discuss with a partner:

What would you do if your world was invaded? Would you have enough courage to stand up against hatred and cruelty? Or would you hide in the shadows of others? Could you play beautiful music for someone, even if they had taken away everything you loved? Would you bring attention to yourself if it meant helping others? Would you cry for yesterday or live for tomorrow? What would you do?

These questions assume a number of basic value judgements: courage, unselfishness, and optimism are good, while hatred, cruelty, cowardice, and defeatism are bad. The book also presents a single-sided view of war, yet the reality is that many of our classrooms have children whose relations represent both sides of a conflict. The assumptions are not necessarily shared by everyone: certainly, the German soldiers in the book talk would have had a very different perspective on things. Yet the book talk does not ask us the textual analysis question, "What if this story were told from the perspective of a different character?" The Harmonica book talk reflects the general stance taken by many of the other book talks. Students are presented with general principles (e.g. "Take care of the planet"); they are not asked to question who gains or who loses through the presentation of these principles nor are they asked what the author is trying to accomplish with the story, but instead to evaluate or measure themselves up against them (e.g. "Do I take care of the planet?")

Few of the pre-service teachers articulated the position that it is the role of the teacher to help students understand that texts present the agenda, purpose and position of the author. Teachers need to help students discern this position because it is a key life skill for students in the $21^{\text {st }}$ century. As noted by Stevens and Bean (2007), "Not being able to negotiate heightened and diverse literacies will certainly prevent our students from accessing a full array of life choices" (p. 19). We find that both the interrogation of the books and the book talks themselves did not attempt to discern the positionalities of the authors.

The social justice book talks reflect the values and beliefs of their creators. Ironically, one could very well submit the book talks to the same critical examination as the books themselves. We asked, "What has been left out of the book talk?" or "What view of the world is the book talk presenting?" Some of the concepts that the pre-service teachers take for granted include:

- Those who are different should be treated with equality and respect

- External differences are not significant; what matters is the heart

- Bullying is bad

- Don't harm others with your words

- We should not live in courage, not defeat

- We should not be selfish 
- Prejudice is bad

- Being careless with the environment/ destroying nature is bad

- We have a right to freedom

Certainly these are values and beliefs that most of us commonly espouse in our classrooms and in our lives. To what degree, however, should we expect our pre-service teachers to examine these pervasive values? Are there some things that should not be questioned? Can we tolerate intolerance, for example? Should we expect everyone to hold to the values of equality and democracy? (What do those words even mean?) If we claim that everyone is entitled to an equal opinion, does this mean that we should allow litterbugs to be litterbugs and Nazis to be Nazis (cf. The Harmonica)? Or are we right to insist that some things are wrong? To what degree does education require us to start with foundational beliefs and morals? To what degree should these beliefs/morals be questioned and challenged in the book talks? These are questions that remained unasked until our debriefing of the assignment and during focus group discussions when many of them were posed to the participating preservice teachers.

\section{The Role of the Teacher as a Moral Compass}

In our class discussions during the screening of the digital book talks, as well as in focus group discussions and in one-on-one interviews with participating pre-service teachers, conversation returned regularly to the role of the teacher when it comes to teaching values and morals. For some, it was difficult to accept that the classroom is not a neutral place and that teachers should explicitly reject the value-neutral understanding of equality and tolerance for a nuanced view in which values such as equality or tolerance are redefined as "Everyone has an equal right to practice their own beliefs so long as those beliefs do not take away another person's life, freedom, etc." Traditionally in schools, the justification for values statements has been based in orthodox religion, reason, and so forth. In Ontario education, for example, teachers are required to "inculcate by precept and example" respect for "principles of Judaeo-Christian morality" (S. 264 (1c), a clear reference to religion as a basis. Within the Ontario Language 1-8 curriculum teachers are directed to plan programs that "encourage students to look beyond the literal meaning of texts and think about fairness, equity, social justice and citizenship in a global society" (Ministry of Education, 1998, p. 23). Here the assumption is that teachers will teach values such as fairness and equity but the document does not state the basis for the values. In Canadian the Human Rights Code (1990) provides a foundation from which beginning teachers can select values. Teachers could also ask which values promote democracy. Most pre-service teachers readily accepted the notion that they would be instrumental in instilling values in their students and many referred to the various character education initiatives currently being undertaken by the district school boards in which they were doing their field placements. Character development initiatives have been required of Ontario's districts of education since 2008. While all of the pre-service teachers acknowledged that they would have to be moral role models for their students, some found this new role somewhat intimidating. Once again, very few articulated an understanding that the role of the literacy teacher is to help students with text deconstruction and reconstruction so that students can see the positional and representational aspects of texts and not accept them as value-neutral.

\section{Discussion and Implications for Initial Teacher Education}

Over a century ago, Dewey (1909) proposed that the role of the school in the teaching of morals was to prepare students for full participation in society. In some respects perhaps it is not wrong - perhaps it is a very good thing - that certain moral positions are assumed by 
the book talks. Questions of social justice cannot be discussed in a moral vacuum, and if the book talks are meant to encourage beneficial social activism, then they must contain an idea of what is beneficial such as saving or squandering environmental resources, showing courage or cowardice. Henry Giroux (1988) reminds us that schools are not neutral spaces.

In short, schools are not neutral sites, and teachers cannot assume the posture of being neutral either. In the broadest sense, teachers as intellectuals have to be seen in terms of the ideological and political interests that structure the nature of the discourse, classroom social relations, and values that they legitimate in their teaching. (p. 127)

As teachers of literacy, we are called to help our students understand that texts are not neutral and that there are interests and purposes behind texts. As Stevens and Bean (2007) remind us, "Texts, in a critical literacy classroom, become sites for explicit conversations that take into account our shifting identities and make students aware of potential imbalances in agency and voice" (p. 25). Pre-service teachers are forming their identity as professionals and we can reasonably anticipate that they are struggling to find their own voice and position as they discuss texts with their students. The book talk assignment in many ways helped them to disrupt previous assumptions and consider new ways of understanding social justice issues. In small groups, they spent time sharing their book talks with each other and engaging in critical readings of the books. The majority of them indicated after the assignment that they felt more comfortable introducing more risky or sensitive issues with their own students; however, a small number were still reluctant.

The digital critical literacy book talk assignment offers a suggestive model of how to effectively use new media as a vehicle for pre-service teachers to begin to explore social justice and equity issues with young students. The book talks and the critical literacy questions provide novice teachers with the opportunity to thoughtfully question and challenge the assumptions that they or others hold. The book talks invited them to evaluate their own actions and attitudes, generally against some already accepted moral standard like equality, freedom, or environmental care, and to brainstorm possibilities for positive social action. In this sense, the book talks encouraged reflective practice and, we hope, will encourage a habit of reflecting on their practice. However, the book talks did not take the further step of investigating and questioning the assumptions present in the book talks themselves and further discussion was required to move them beyond the creation of the book talks to a more critical analysis of them. It is clear that such deeper questions are beneficial, if for no other reason than to help beginning teachers understand their own identity i.e., what they believe and why and what their role as a teacher will be in regards to teaching morals and values. This finding reminds us that critical literacy may not have been present in the pre-service teachers' own early education, and some of the them will need more time and modeling in order to see critical literacy as something that accomplished readers do.

In terms of our own practice, we have realized that we need to spend more time when introducing the assignment, working with the pre-service teachers to critique the sample book talks and to problemetize the issues reflected in them as a way of rendering some of the underlying assumptions in them more visible. We also need to address the tension that exists between trying to persuade students to read a text and introducing them to the critical literacy skill of deconstructing a text. The assignment to develop a digital book talk based on a social justice issue did encourage the pre-service teachers to immerse themselves in digital media and to consider how they might use a book talk as a way to enter into discussion about sensitive issues with their students. 


\section{References}

Agarwal, R., Epstein, S., Oppenheim, R., Oyler, C. \& Sonu, D. (2010). From ideal to practice and back again: Beginning teachers teaching for social justice. Journal of Teacher Education, 61, 237-247.

Berlak, A., \& Moyenda, S. (2001). Taking it personally: Racism in the classroom from kindergarten to college. Philadelphia: Temple University Press.

Bearne, E. (2003). Rethinking literacy: Communication, representation, and text. Reading Literacy and Language, 37(3), 98-103.

Bigelow, B., Harvey, B., Karp, S., \& Miller, L. (2001). Rethinking our classrooms: Teaching for equity and justice. Vol. 2. Milwaukee, WI: Rethinking Schools, Ltd.

Christensen, L. (2001). Reading, writing, and rising up: Teaching about social justice and the power of the written word. Milwaukee, WI: Rethinking Schools, Ltd.

Christensen, L. (2009). Teaching for joy and justice. Milwaukee, WI: Rethinking Schools.

Cochran-Smith, M. (2004). Walking the road: Race, diversity and social justice in teacher education. New York: Teachers College Press.

Darling-Hammond, L., French, J., \& Garcia-Lopez, S. P. (2002). Learning to teach for social justice. New York: Teachers College Press.

Derman-Sparks, L., \& Ramsey, P. (2006). What if all the kids are White? Anti-bias, multicultural education with young children and families. New York: Teachers College Press.

Dewey, J. (1990). Moral principles in education. Riverside Educational Monographs (e-book \# 25172).

“Education Act." In Revised Statutes of Ontario, 1990. Chapter E-2. Ottawa: Queen's Printer of Ontario, 1990.

Fischbaugh, R. (2004). Using book talks to promote high-level questioning skills. The Reading Teacher, 58(3), 296-299.

Kelly, D. \& Brandes G. (2001). Shifting out of "neutral": Beginning teachers' struggles with teaching for social justice. Canadian Journal of Education 26 (4), 437-454.

Gilmore, D. \& Bell, K. (2006). We are family. Using diverse family structure literature with children. Reading Horizons Journal, 46 (4), 279-299.

Giroux, H. (1988). Teachers as intellectuals: toward a critical pedagogy of learning. Westport, CT: Bergin \& Garvey Publishers, Inc.

Hughes, J. \& Robertson, L. (2010). Transforming practice: Using digital video to engage students. Contemporary Issues in Technology and Teacher Education (CITE). Special Issue: Digital Video, 10(1), 20-37. ISSN: 1528-5804. Available online: http://www.citejournal.org/vol10/iss1/languagearts/article2.cfm

Jewitt, C. (2008). Technology, literacy and learning: A multimodal approach. NY: Routledge.

Kumashiro, K. (2004). Against common sense: Teaching and learning toward social justice. New York: Routledge Falmer.

Leland, C., Harste, J. \& Smith, K. (2005). Out of the box: Critical literacy in a first-grade classroom. Language Arts, 82 (4), 257-268.

Mayer, R. (2008). Multimedia literacy. In J. Coiro, M. Knobel, C. Lankshear \& D. Leu (Eds.), Handbook of research on new literacies. New York: Lawrence Erlbaum Associates.

McIntosh, P. (2008). White privilege and male privilege: A personal account of coming to see correspondences through work in women's studies. In G. C. Gamst, A. Der- 
Karabetian, \& R. H. Dana (Eds.), CMBCS multicultural reader. Thousand Oaks, California: Sage Publications Ltd, 572.

Moller, K. (2002). Providing support for dialogue in literature discussions about social justice. Language Arts, 79 (6), 467-476.

New London Group. (1996). A Pedagogy of Multiliteracies: Designing Social Futures. Harvard Educational Review, 66(1), 60-92.

Oakes, J., \& Lipton, M. (2007). Teaching to change the world ( $3^{\text {rd }}$ ed.). New York: McGrawHill.

O'Neil, K. (2010). Once upon today: Teaching for social justice with postmodern picturebooks. Children's Literature in Education, 41, 40-51.

Ontario Human Rights Code. (1990). Available http://www.elaws.gov.on.ca/html/statutes/english/elaws_statutes_90h19_e.htm

Robertson, L. \& Hughes, J. (2010). The teachers they are becoming: Multiple literacies in teacher pre-service. International Journal of Knowledge Society Research, 1(2), 3849.

Schniedewind, N., \& Davidson, E. (2006). Open minds to equality: A sourcebook of activities to affirm diversity and promote equity, (3rd ed.). Milwaukee, WI: Rethinking Schools.

Selber, S. (2004). Multiliteracies for a digital age. Carbondale, Ill.: Southern Illinois University Press.

Short, K., Kauffman, G. \& Kahn, L. (2000). "I just need to draw": Responding to literature across multiple sign systems. The Reading Teacher, 54(2), 160-171.

Sleeter, C. (2005). Un-standardizing curriculum: Multicultural teaching in the standardsbased classroom. New York: Teachers College Press.

Stake, R. (2000). Case studies. In .N. Denzin \& Y. Lincoln, (Eds.), Handbook of qualitative research, $2^{\text {nd }} E d$. 435-454. Thousand Oaks, CA: Sage.

Stevens, L. \& Bean, T. (2007). Critical literacy: Context, research, and practice in the K-12 classroom. Thousand Oaks, CA: Sage.

Soohoo, S. (2006). Falling leaves: Narratives of otherness. Cresskill, NJ: Hampton Press.

Wade, R. (2007). Social studies for social justice: Teaching strategies for the elementary classroom. New York: Teachers College Press.

Wilhelm, J. (1995). Creating the missing links: Student-designed learning on hypermedia. English Journal, 84(6), 34-40.

Wolk, S. \& Labbo, L. (2004). Using picture books to teach for democracy. Language Arts, 82(1), 26-35.

\section{Author Biography}

Janette Hughes is Assistant Professor in the Faculty of Education at the University of Ontario Institute of Technology. Her research interests are in new literacies in general, with particular emphasis on digital literacies. Janette.Hughes@uoit.ca

Lorayne Robertson is Assistant Professor and Graduate Program Director in the Faculty of Education at the University of Ontario Institute of Technology. Her research interests include digital literacy, critical literacy and media literacy. Lorayne.Robertson@uoit.ca 